\title{
Is conservative reporting attractive to foreign institutional investors? Evidence from an emerging market
}

\author{
Yilmaz Yildiz \\ Hacettepe University, Department of Business Administration \\ yilmazyildiz@hacettepe.edu.tr \\ Mehmet Baha Karan \\ Hacettepe University, Department of Business Administration \\ mbkaran@hacettepe.edu.tr \\ Aydin Ozkan \\ University of Huddersfield, Business School \\ a.ozkan@hud.ac.uk
}




\title{
Is conservative reporting attractive to foreign institutional investors? Evidence from an emerging market
}

\begin{abstract}
This study investigates the relation between conservative reporting and foreign institutional ownership using a unique dataset of firms in Turkey. In doing so, we distinguish between foreign funds and corporations. Contrary to prior findings, our analysis shows that conservative reporting is not necessarily a desirable accounting feature for foreign institutional investors. We also find that the interplay between conservative reporting and ownership is significantly different between foreign funds and corporations. The estimated negative relation holds only for foreign funds. Further analysis reveals that foreign funds do not find conservative reporting desirable in low-asymmetric information firms and reduce ownership with greater accounting conservatism in such firms. The analysis sheds significant lights on the relevance of conservative reporting in alleviating the negative consequences of asymmetric information.
\end{abstract}

Keywords: Foreign institutional investors; conservative reporting; information asymmetry; emerging market.

JEL Classification: G11, G15, G23, M41 


\section{Introduction}

This paper investigates the equity investment decisions of foreign institutional investors in an emerging market setting. Specifically, it empirically examines the firm-level determinants of foreign institutional ownership in Turkey, an emerging market characterized by a high degree of information asymmetry between inside and outside investors. There are three important features of the analysis, which also constitute the main contributions of this study. First, in addition to the usual firm-specific factors which are considered in prior research, we consider how conservative reporting (also known as accounting conservatism) impacts the equity investment decisions of foreign institutional investors. Second, we investigate the role of information asymmetry and monitoring within firms in determining the nature of the relationship between conservative reporting and foreign institutional ownership. Third, in conducting our investigation we distinguish between foreign funds and foreign corporate investors, which have different investment and risk-taking behaviour. ${ }^{1}$

Previous research on foreign institutional ownership mostly draw inferences on the information asymmetry view (see, e.g., Kang and Stulz 1997; Dahlquist and Robertsson 2001; Choe, Kho, and Stulz 2005). It is argued that foreign investors are generally less informed than domestic investors, which makes the availability and quality of relevant information more crucial for their investment decisions. In investing in the domestic market, foreign institutional investors are expected to choose firms with lower levels of asymmetric information. In support of this view, it is shown that foreign investors tend to invest in firms that are listed on foreign stock exchanges and those with greater market capitalization and international sales. ${ }^{2}$

It is known that the costly manager-shareholder agency conflicts result in lower firm value when shareholders cannot monitor the management effectively (Jensen and Meckling 1976). In our setting, the main agency problem is expected to arise between corporate insiders (managers acting in domestic controlling shareholders' interests) and outsiders (foreign investors). 
Previous research shows that both asymmetric information and related agency problems influence the levels of foreign institutional ownership (see, e.g., Aggarwal, Klapper, and Wysocki 2005; Leuz, Lins, and Warnock 2008; Min and Bowman 2015; Giannetti and Simonov 2006; Jiang and Kim 2004). Differently from earlier work, this study focuses on the role of accounting conservatism in impacting the decisions of foreign institutional investors in an environment associated with significant agency and asymmetric information issues.

Incorporating accounting conservatism in the analysis of foreign institutional ownership is one of the novelties of this study. It is argued that accounting conservatism reduces asymmetric information between insiders and outsiders (LaFond and Watts 2008). Our a priori prediction is hence that foreign investors invest more in firms with greater conservatism. However, we also point out that conservative accounting can be perceived by outsiders as a symptom of significant informational problems within the firm. This would in turn reduce the ownership incentives of foreign investors.

Another important aspect of our study concerns with the type of institutional investors. Previous studies on the determinants of foreign equity ownership either considers foreign investors as a homogenous group (Kang and Stulz 1997; Dahlquist and Robertsson 2001; Min and Bowman 2015) or focuses only on the preferences of foreign mutual funds (Covrig, Lau, and Ng 2006; Liu et al. 2014; Zou, Tang and Li 2016). In this study, we explicitly distinguish between the ownership choices of foreign funds and foreign corporations. It is argued that their investment motivations are different (Douma, George, and Kabir 2006). Given that foreign financial institutions generally have a shorter investment horizon, they are expected to engage less in monitoring of firm management. Instead, they actively manage their portfolio and sell the poorly performing stocks, focusing on the short-term stock return performance rather than the capability of firms to create long-term shareholder value. On the other hand, foreign 
corporate investors are more likely to pursue long-term value and hence are also interested in the strategic goals of the firms they invest in.

Our study employs a unique dataset from Turkey using 192 firms and 1,791 firm-year observations over the period 2006-2015. Turkey provides an ideal setting to investigate the research questions related to foreign institutional ownership. Similar to other emerging markets, capital markets in Turkey are prone to information asymmetry and agency problems. It is characterized as a code law country with low levels of judicial quality and public enforcement on securities, lower investor protection and transparency in accounting disclosures. ${ }^{3}$ It is also important to note that Turkey is also free from restrictions in terms of foreign capital inflows and outflows, which enables us to conduct the analysis without getting concerned about the barriers in capital flows. Finally, the presence of foreign investors is very significant. About $63 \%$ of the publicly traded shares in Turkey is held by foreign investors as of $2015 .{ }^{4}$

In our analysis, in addition to the common firm control variables we also incorporate several important ownership and board characteristics, including insider shareholdings and information on the board membership of foreign directors. Our findings provide strong evidence that the factors determining the equity ownership of foreign funds and corporations in domestic firms are significantly different. Foreign funds tend to invest in firms with high cash, dividend and leverage, whereas the reverse is valid for the foreign corporations in the sample. However, both investor groups acquire greater ownership in large firms and firms with high growth options. More importantly, our analysis provides strong evidence that conservative reporting is not necessarily desirable for foreign investors. It affects negatively the equity investment of foreign institutional investors. However, a more detailed investigation reveals that the interplay between conservative reporting and ownership is significantly different between foreign funds and corporations. Specifically, conservative reporting is important only in determining the investment decisions of foreign funds, whereas foreign corporations are 
indifferent towards the degree of conservative reporting. More interestingly, foreign funds reduce ownership in low-asymmetric information firms with conservative reporting practices. Last but not least, our results indicate that the negative relation between conservative reporting and the equity investment decisions of foreign funds becomes stronger after the global financial crisis. These findings are important not only to understand better the factors that influence the investment decisions of foreign institutional investors in emerging markets, but also to shed significant lights on the relevance of accounting practices in alleviating the negative consequences of conservative reporting. Our results are robust to alternative methods of estimations and measures of foreign institutional ownership.

The remainder of the paper proceeds as follows. Section 2 gives a brief background on the main arguments and predictions of the paper. Section 3 describes the sample data and the methodology used in the analysis. In Section 4 and 5, we present the results from the main analysis and the additional tests. Finally, Section 6 concludes the paper.

\section{Background and predictions}

\subsection{Accounting conservatism and foreign institutional investment: two opposing views}

Basu (1997) defines accounting conservatism as "resulting in earnings reflecting the bad news more quickly than good news", which is also seen as the asymmetric verification of goods versus bad news. The main arguments on the role of conservative reporting within firms revolve around the view that conservative accounting is a response to costly information asymmetries between insiders and outsiders of firms. (LaFond and Watts 2008). However, several papers also stress the influence of conservative reporting on corporate financial decisions and more importantly on firm performance. For example, Kravet (2014) argues that accounting conservatism reduces the incentives of managers to invest in risky projects since economic losses are reported in a more timely manner in a conservative reporting regime. This in turn restrains financial managers in deferring the losses associated with the risky acquisitions. 
Therefore, greater conservative reporting decreases the riskiness of the firm by motivating the managers to reduce uncertainty regarding investment decisions. However, it is also important to note that greater risk aversion may lead to positive NPV projects to be passed up, which would in turn reduce firm value. Consequently, while risk-averse investors may prefer conservative firms, investors who seek greater return may avoid investing in such firms.

Although there is some evidence in the literature on the role of institutional ownership in contributing to conservative reporting (see, e.g., LaFond and Roychowdhury 2008; Ramalingegowda and Yu 2012), the relationship between accounting conservatism and foreign institutional ownership has not been investigated. In this study, we attempt to fill this gap and present below two opposing views about the impact of accounting conservatism on the investment preferences of foreign institutional investors. In the following, we discuss how and why accounting conservatism can be related to the preferences of foreign institutional investors.

Prediction 1. Foreign investors invest more in firms with greater conservatism, leading to a positive relation between accounting conservatism and foreign institutional ownership.

This is based on the view that conservative reporting curbs the incentives of managers to manipulate information and hence alleviates the agency conflicts between insiders and outsiders. Thus, firms with conservative reporting practices provide more reliable and verifiable information to the public, which in turn reduce the monitoring costs borne by outside investors (Basu 1997; Watts 2003; Khan and Watts 2009). This argument is supported with the evidence provided in the literature that conservative reporting reduces information uncertainty and the information asymmetry within the firm (Lara, Osma, and Penalva; Lin and Tian 2012).

There are also additional benefits of accounting conservatism reported in the literature, which may be attractive to foreign institutional investors. For example, Suijs (2008) proposes that conservative reporting leads to higher firm value and increases risk sharing efficiency by 
reducing the dispersion of the future stock prices. Lara, Osma, and Penalva (2011) empirically test the value relevance of conservatism showing that it reduces the uncertainty of future cash flows, the cost of capital and consequently increases firm value. Kim and Zhang (2016), using a sample of US firms for the period 1964-2007, find that accounting conservatism mitigates the likelihood of stock price crash risk by preventing the accumulation of bad news. Similarly, Ahmed and Duellman (2013) find a negative relationship between managerial overconfidence and accounting conservatism. This feature of accounting conservatism may be desirable by foreign institutional investors since overconfident or optimistic managers tend to perceive negative NPV projects as positive and in turn lower firm value by investing in them. The role of conservative reporting in reducing risk and lowering the cost of capital is especially important for foreign investors who are informationally disadvantaged about the local stocks. In the presence of significant informational costs, investors who are more prone to asymmetric information problems are expected to invest in firms with greater conditional conservatism ${ }^{5}$.

Prediction 2. Foreign investors invest less in firms with greater conservatism, leading to a negative relation between accounting conservatism and foreign institutional ownership.

It is argued that current losses are reflected in financial statements in a timely manner if the informational asymmetry between informed insiders and uninformed outsiders is greater. Therefore, in the absence of an alternative measure of asymmetric information, foreign investors might perceive accounting conservatism as an indication of severe informational asymmetry problems, rather than a mechanism which mitigates the agency problems. Moreover, low levels of conservatism can be used by managers as a signaling device to distinguish themselves from the other firms which suffer from information asymmetries (Allen and Faulhaber 1989). Additionally, Roychowdhury (2010) argues that accounting conservatism can be costly if managers tend to avoid risky projects with positive net present value, resulting 
in lower firm value. Supporting this argument, Kravet (2014) find that conservative managers are less likely to invest in risky projects to minimize the possibility of large losses. This feature of conservative reporting may be less desirable to investors who seek short-term profits rather than long-term engagement with the firm. Finally, Bertomou, Darraough, and Xue (2017) argue that there is an optimal level of accounting conservatism. Although conservative reporting partly reduces earnings manipulation, higher than optimal levels of conservatism increases the aggressiveness of earnings and discourage foreign investors to take equity ownership.

\subsection{Foreign funds vs foreign corporations}

Although there are previous studies that focus on the investment preferences of foreign mutual funds (e.g., Covrig, Lau, and Ng 2006; Liu et al. 2014; Zou, Tang and Li 2016), the majority of previous studies on foreign institutional ownership consider foreign investors as a homogenous group (see, e.g., Kang and Stulz 1997; Dahlquist and Robertsson 2001; Min and Bowman 2015). The comparison of portfolio holding decisions of foreign funds and foreign corporate investors is often neglected. In this paper, we attempt to address this issue by investigating the preferences of foreign funds and foreign corporations separately. Douma, George, and Kabir (2006) show that foreign corporations outperform foreign funds in terms of portfolio performance, suggesting that foreign funds and corporations invest in different risky assets. Prior research on the preferences of institutional investors also suggest that investors should be disaggregated as dedicated and transient since the former group has a long-term investment horizon and engage in more direct monitoring. Conversely, transient investors are more likely to seek short-term profits, have higher turnover and less monitoring activities (Ramalingegowda and Yu 2012).

Prediction 3. The relationship between conservative reporting and ownership is expected to be stronger for foreign funds than foreign corporations. 
In line with prior research, we argue that foreign funds and foreign corporations invest in different assets due to their varying motivations and information endowment. Foreign corporations are generally characterized as strategic owners. They have capital and technology commitment in the company beyond equity participation (Douma, George, and Kabir 2006). Therefore, they are more interested in the control and monitoring issues and hence less sensitive to accounting practices within the firm. On the other hand, foreign funds are more interested in short-term profitability than long-term monitoring and hence put more weight on the short-term consequences of conservative reporting. Differently than foreign corporate investors, foreign funds tend to sell their shares if they are not satisfied with the performance of the stock. Moreover, due to risk reduction motives, foreign funds tend to diversify their investment over different firms and industries (Douma, George, and Kabir 2006). This in turn makes them more strongly focused on short-term profits and less so in the long-term value of the company.

Furthermore, we argue that the predicted negative relationship between the ownership of foreign funds and accounting conservatism would be stronger in firms with lower information asymmetry and greater monitoring effectiveness. Since foreign funds seek short-term profits rather than long-term engagement with the firm, the cost of conservatism can be even more pronounced in firms which are exposed to a lower level of information asymmetry. Assuming that accounting conservatism is a response to the presence of information asymmetry within the firm, it can be less desirable for foreign funds. On the other hand, foreign corporations generally make long-term strategic investments rather than seeking short-term gains. This in turn reduces the negative sensitivity of their investment decisions to asymmetric information, proxied by the extent of accounting conservatism. 


\section{Data and Methodology}

\subsection{Data and Sample Selection}

We use in our analysis a large sample of firms listed on Borsa Istanbul during the sample period 2006-2015. The choice of the sample period is partly driven by the adoption of the International Financial Reporting System (IFRS) by Turkish firms in 2005. The IFRS is important for the comparability of the accounting practices such as conservatism with the other emerging and advanced markets. Turkey has also taken steps to enhance the corporate governance quality. For example, in 2007 corporate governance index was formed by Borsa Istanbul (formerly IMKB) to motivate the publicly listed corporations to implement the globally accepted governance principles. Also, it is required that the publicly listed firms in Turkey should appoint independent board members which should make at least one third of the board. In 2011, the Turkish Commercial Code was changed making independent auditing mandatory. Moreover, Public Oversight Accounting and Auditing Standards was formed in the same year as an authority to issue the accounting standards compliant with the IFRS and monitor independent auditors and audit firms. We select firms which are non-financial, do not have any missing data, and have at least two years of consecutive observations since. We also exclude observations in top and bottom percentile of the initial sample with respect to the main variables of interest to control for the impact of outliers. Our final sample consists of 192 firms and 1,791 firm-year observations. Foreign ownership data for each firm is obtained from the Central Securities Depository of Turkey, a government organization keeping the domestic corporate ownership records. The financial market and accounting data, excluding the foreign sales, are obtained from the Datastream. Data for foreign sales and governance variables are acquired from the company annual financial reports.

In this study, we employ three different definitions of foreign institutional investment in estimations, namely total foreign institutional ownership (FIO), foreign funds ownership (FFO) 
and foreign corporation ownership (FCO). For each firm, FIO is calculated by dividing the total ownership of foreign institutional investors with the float-based market capitalization of firms. FFO is the ratio of foreign funds holdings to the float-based market capitalization. Similarly, FCO is the ratio foreign corporation holdings to the float-based market capitalization. We use the float-based market capitalization in defining the dependent variables as the vast majority of firms in our sample have significant shareholdings by insiders, which lowers the foreign ownership ratio (Dahlquist et al. 2003; Kang, Lee, and Park 2010). For robustness purposes, we also use alternative measures of foreign ownership.

In Table 1, we give the definitions of the dependent and explanatory variables used in the analysis. In the following, we discuss how we measure accounting conservatism and briefly explain the relevance of each variable in determining the foreign ownership.

$<<$ Please insert Table 1 about here $>>$

\section{Accounting and Market Variables}

Size. Previous work emphasizes that foreign investors tend to invest in large firms. The main reason is that both the quantity and quality of information released by large firms are greater, leading to a reduced level of asymmetric information which foreign investors are more prone to (Kang and Stulz 1997; Covrig, Lau, and Ng 2006; Liu et al. 2014). We use natural logarithm of total assets as a proxy for firm size.

Cash. The implications of cash holdings for foreign institutional ownership are twofold. On one hand, firms with greater investment opportunities are expected to hold more cash as they desire to smooth their investment expenditures by absorbing the volatility in their cash flows (Opler et al. 1999). On the other hand, managers have tendency to hold excessive cash balances as they can exercise discretion over the use of cash reserves, enabling them to invest in negative NPV projects and spend cash on non-pecuniary benefits (Jensen 1986; Harford, Mansi, and Maxwell 2012; Ozkan and Ozkan 2004). In short, cash holdings of firms can indicate either better growth 
opportunities or costly agency problems, leading to a prediction that is not clear-cut. We use the ratio of cash and equivalents to total assets as a proxy of the cash level of the firm.

Leverage. It is well-documented that capital structure of firms has a significant impact on investor preferences. However, how corporate leverage is perceived by foreign investors is not clear-cut. The probability of financial distress is greater for firms with higher levels of leverage, which would in turn reduce the incentives of foreign investors to invest in high-leverage firms. However, leverage can also be considered as a corporate governance mechanism that enhances value for shareholders by mitigating the agency problems within firms (Harvey, Lins, and Roper 2004). It is also known that firms can use leverage as a signaling device about their quality and financial strength (Ross 1977). We use the ratio of total debt to total assets as a proxy of the capital structure decisions of the firms.

Dividend. It is well known that paying out dividends is perceived by the market as a signal for a greater expected future firm performance. High dividend payout also mitigates the agency problems within firms by reducing the free cash flow available to managers. In line with this argument, La Porta et al. (2000) argue that shareholders demand higher dividend from firms especially in less developed countries characterized by weaker corporate governance. Additionally, firms paying high dividends need to raise capital, which increases the monitoring power of outside parties. We use the ratio of total dividends paid to the market capitalization of the firm as a proxy for the dividend payments.

Growth opportunities. Firms with greater growth opportunities are more likely to suffer from agency and information asymmetry problems. However, high-growth firms are also associated with better future performance, which may attract more investment by foreign investors (Fama and French 1995). In line with these opposing arguments, prior evidence on the relation between foreign ownership and market-to-book ratio is mixed. Dahlquist and Robertsson (2001) report a positive relationship, while Lin and Swanson (2003), and Zou, Tang and Li (2016) find that 
foreign investors prefer firms with lower growth opportunities. We use the market-to-book ratio as a proxy for their growth prospects, measured by the ratio of book value of total assets minus the book value of equity plus the market value of equity to book value of assets.

Export. The level of exports is widely regarded as a tool which mitigates the extent of information asymmetry between domestic and foreign investors. It is argued that foreign investors tend to invest in firms with more international operations since they are more visible to foreign investors (Covrig, Lau, and $\mathrm{Ng}$ 2006). We measure exports as the ratio of foreign sales to total sales.

Turnover. We include the ratio of average daily trading volume over the year to the number of shares outstanding to account for stock liquidity. Previous evidence suggests that foreign investors prefer stocks with higher level of liquidity as it is simply less costly to acquire information about more liquid stocks (Kang and Stulz 1997; Dahlquist and Robertsson 2001).

Profitability. The accounting performance of firms is also expected to have an impact on the investment decisions of foreign investors as the recent performance of firms is a strong proxy for their future viability. Consistent with this argument, prior research reports a positive relationship between accounting performance and foreign ownership level (Kang and Stulz 1997; Liu et al. 2014). We include in the analysis the ratio of net income before extraordinary items to total assets (ROA).

Local and global alpha. In addition to accounting performance, the market performance of stocks is also expected to be crucial in determining the investment decisions of investors. Prior research finds that foreign investors tend to buy the past winning stocks and sell past losers (Grinblatt and Keloharju 2000; Lin and Swanson 2003). We employ two measures of market performance: local and global alpha. Following Kang, Lee, and Park (2010), we propose the following valuation model to account for the local performance of each stock: 


$$
R_{i, t}=\alpha_{i}^{D}+\beta_{i}^{D} R_{D, t}+\varepsilon_{i, t}^{D}
$$

Where $R_{i, t}$ and $R_{D, t}$ correspond to the daily excess return of the stock and benchmark index in local currency (Turkish Lira) respectively. In deriving the returns, we use the 3-months treasury bill rate of government bonds as the risk-free rate. We also use BIST100 Index as our local benchmark. In order to obtain the risk-adjusted local performance measure for the stock, we divide the $\alpha_{i}^{D}$ by the standard deviation of the error terms $\left(\varepsilon_{i, t}^{D}\right)$. This resultant $\alpha$ level can be considered as the local risk-adjusted (scaled) performance of the each stock (Local alpha).

Kang, Lee, and Park (2010) suggest that local and foreign investors use different asset valuation models. More specifically, foreign investors use a global benchmark in their asset valuation models whereas local investors base their valuation in local criteria. Thus, foreign investors tend to invest in stocks which perform relatively better globally whereas local investors prefer stocks which provide better local performance. Similar to the estimation of local performance, we use the following model to obtain the global performance of each stock as follows:

$$
R_{i, t}=\alpha_{i}^{F}+\beta_{i}^{F} R_{F, t}+\varepsilon_{i, t}^{F}
$$

In Equation (2), $\alpha_{i}^{F}$ indicates the daily return of the of the $\mathrm{i}^{\text {th }}$ stock in time $t$ over or below the benchmark. $R_{i, t}$ and $R_{F, t}$ corresponds respectively to the daily excess returns in time $t$ of the $\mathrm{i}^{\text {th }}$ stock and the benchmark index (in dollars). We use the 3-months eurodollar rate as the global risk-free rate and the MSCI World Index for the benchmark index. In order to find the risk adjusted global performance measure of the stock, we divide the $\alpha_{i}^{F}$ with the standard deviation of the error terms $\left(\varepsilon_{i, t}^{F}\right)$. This risk-adjusted $\alpha$ can be considered as the global risk-adjusted performance of the stock (Global alpha).

Finally, to dissociate the local and global performance measures, we orthogonolize Global alpha with Local alpha as follows: 


$$
\text { Global alpha } a_{i, t}=\text { Local alpha } a_{i, t}+\varepsilon_{i, t}
$$

In equation (3), we regress the risk adjusted (scaled) Global alpha on the risk-adjusted Local alpha and estimate the error terms for each year. The estimated error terms correspond to the risk-adjusted global performance of each stock, purified from the local effect. We call this new variable as Global alpha ${ }^{\text {ort }}$.

\section{Governance Variables}

Corporate governance practices of firms are among the important determinants of foreign ownership. As discussed earlier, foreign investors are informationally disadvantaged than the domestic investors about the local firms, the expropriation of outside investors by insiders and the monitoring of firm management are hence expected to be significant for the investment decisions of foreign investors. In support of this view, Leuz, Lins, and Warnock (2008) find that both firm- and country-level governance variables have a considerable impact on foreign shareholdings. They show that foreign investors invest less in poorly governed firms since good governance practices mitigate the potential agency conflicts and increase monitoring efficiency. We incorporate in the analysis four different firm governance characteristics, namely board size, board independence, the number of foreign board members and insider ownership. Below we briefly discuss the relevance of each governance variable on the preferences of foreign institutional investors.

Board Size. The nature of the relationship between board size and foreign institutional ownership is not clear-cut. On one hand, larger boards are expected to cause greater communication problems and agency conflicts, leading to an inefficient and slower decision making and in turn a lower level of corporate performance (Guest 2009). In addition, the influence of CEOs on the corporate decisions become more visible in larger boards (Jensen 1993). On the other hand, better diversified larger boards are likely to reduce the likelihood of 
the value reducing riskier investment decisions. Therefore, firms with larger boards are expected to have less volatility in their performance, which is likely to attract foreign investors (Cheng 2008). We use the total number of board of directors as a measure of board size.

Board independence. The independence of the board of directors is central in monitoring and preventing the expropriation of outside investors by the firm's insiders. In a setting where inside ownership is significant, the presence of independent directors is crucial for the foreign investors in alleviating the agency conflicts between insiders and minority shareholders (Fama and Jensen 1983). The monitoring of insiders by the independent board members is likely to mitigate the expropriation of minority interests and motivate foreign investors to invest more in firms with a greater number of independent directors. We use the ratio of independent board members to the total number of board members as a measure of board independence.

Foreign directors. The appointment of foreign directors to board can have a considerable impact on firm value by inducing effective monitoring. However, the literature on the influence of foreign directors on performance and governance practices provides opposing arguments. The presence of foreign investors on the board can be taken as a favorable board characteristic as foreign directors are generally more experienced and knowledgeable about the international markets and standards (Adams, Hermalin, and Weisbach 2010). In contrast, due to geographic distance from the headquarters, foreign directors can reduce the monitoring effectiveness of the board as they are more likely to miss board meetings (Masulis, Wang, and Xie 2012). This variable is defined as the ratio of the number of foreign board directors to board size.

Insider ownership. In a setting where the predominant type of corporate ownership is family ownership, the free-float ownership is expected to influence the preferences of foreign investors significantly. Greater levels of insider ownership may not be attractive to strategic or corporate investors since they are not able to have enough influence and control over the long-term 
decisions. We define insider ownership by the ratio of the total value of closely-held shares to the market capitalization of the firm.

\section{Measure of accounting conservatism - C_Score}

Our measure of accounting conservatism is the C_Score which is developed by Khan and Watts (2009). This measure of conservatism is based on the seminal paper of Basu (1997). To test the relationship between stock returns which are expected to lead current earnings, Basu (1997) proposes the following regression:

$$
N I_{i, t}=\beta_{0}+\beta_{1} N e g_{i, t}+\beta_{2} \operatorname{Ret}_{i, t}+\beta_{3} N e g_{i, t} * \operatorname{Ret}_{i, t}+\varepsilon_{i, t}
$$

where $N I$ is the income before extraordinary items scaled by the beginning of the year market value of equity; Ret is the annual market adjusted-return of the stock calculated by compounding monthly returns starting from the 3 months after the fiscal year; Neg is a dummy variable takes the value of 1 if the Ret is negative, 0 otherwise. $i$ and $t$ represent firm and year subscripts, respectively. Since it is expected that bad news are incorporated in current earnings in a more timely manner, the coefficient of the interaction term which indicates the conditional conservativism level $\left(\beta_{3}\right)$ should be higher than $\beta_{2}$.

As it is discussed in several papers (i.e. Basu, 1997; Ball, Kothari, and Nikolaev 2012; Andre, Filip, and Paugam 2015) country-level factors such as the legal enforcement, investor protection, stock market risk etc. have a strong influence on the conservative reporting practices of the firms. Since the proposition of Basu (1997) depends on the stock market returns as a measure of good/bad news, the current state of the domestic market is expected have an impact on the conservatism measure. For example, stock prices have experienced significant drop in Borsa Istanbul as a whole during the global crisis period similar to other emerging markets but they started to increase in a short period when the negative impact of crisis has reduced. Therefore, it may be misleading to use nominal returns rather than market-adjusted returns since 
nominal returns do not account for the unexpected part of the return (Ball, Kothari, and Nikolaev 2012). Using market-adjusted return enables us to avoid country-specific factors which is an issue particularly important for emerging markets which are generally regarded as more sensitive to the external shocks such as global financial crisis.

To derive a measure of conservatism which accounts for the cross-sectional variation of firm-specific characteristics, Khan and Watts (2009) extend the original model of Basu (1997) and include additional variables such as firm size, leverage and market-to-book ratio which are assumed to be directly related with conservatism. The model is given by the following equation

$$
\begin{aligned}
N I_{i, t}= & \beta_{0}+\beta_{1} \operatorname{Neg}_{i, t}+\operatorname{Ret}_{i, t}\left(\mu_{1}+\mu_{2} \operatorname{Size}_{i, t}+\mu_{3} \operatorname{Lev}_{i, t}+\mu_{4} M B_{i, t}\right. \\
& +\operatorname{Ret}_{i, t} \operatorname{Neg}_{i, t}\left(\gamma_{1}+\gamma_{2} \operatorname{Size}_{i, t}+\gamma_{3} \operatorname{Lev}_{i, t}+\gamma_{4} M B_{i, t}\right) \\
& +\left(\delta_{1} \operatorname{Size}_{i, t}+\delta_{2} \operatorname{Lev}_{i, t}+\delta_{3} M B_{i, t}+\delta_{4} \operatorname{Neg}_{i, t} \operatorname{Size}_{i, t}\right. \\
& \left.+\delta_{4} \operatorname{Neg}_{i, t} \operatorname{Lev}_{i, t}+\delta_{4} \operatorname{Neg}_{i, t} M B_{i, t}\right)+\varepsilon_{i, t}
\end{aligned}
$$

where Size is the natural logarithm of the market value of equity, Lev is the ratio of total debt to the market value of equity and $M B$ is the market-to-book ratio.

To obtain a firm-specific measure of conditional conservatism, we first cross-sectionally estimate Equation (5) and then use the estimated coefficients of interaction terms $\left(\gamma_{1}\right.$ to $\left.\gamma_{4}\right)$ to calculate the year- and firm-specific conservatism measure (C_Score) as follows:

$$
C_{-} \text {Score }_{i, t}=\gamma_{1}+\gamma_{2} \text { Size }_{i, t}+\gamma_{3} \text { Lev }_{i, t}+\gamma_{4} M B_{i, t}
$$

It should be noted that in Equation (6) $\gamma_{1}$ to $\gamma_{4}$ reflect not only the firm-specific but also the time-variant aspect of accounting conservatism as the estimations are achieved through a series of cross-sectional estimations for each year in the sample.

Although legal and institutional factors affect the degree of conservative reporting at both firm and country levels, the earnings-return relationship proposed by Basu (1997) and C_Score are widely used in measuring conditional conservatism in both advanced and emerging markets. 
C_Score is regarded as a more effective measure of firm-level conditional conservatism than other measures such as the skewness of earnings to cash flows and the accumulation of nonoperating earnings since they are likely to capture both conditional and unconditional conservatism (Lara, Osma, and Penalva 2016). C_Score is, therefore, adopted in many studies which focus on both single country investigations and international comparisons (Andre, Filip, and Paugam 2015; Li 2015). Moreover, incorporating market-adjusted returns in the coefficient estimation as discussed above is expected to purify the market-specific effects on the C_Score and mitigates the concerns about the appropriateness of this measure in an emerging market.

\subsection{Empirical Model}

To investigate the empirical determinants of the investment decisions of foreign institutional investors, we estimate the following model:

$$
\begin{aligned}
\text { FO }_{i, t}=\alpha & +\beta_{1} \text { C_Score }_{i, t-1}+\beta_{2} \text { Size }_{i, t-1}+\beta_{3} \text { Cash }_{i, t-1}+\beta_{4} \text { Leverage }_{i, t-1} \\
& +\beta_{5} \text { Dividend }_{i, t-1}+\beta_{6}{\text { Market to } \text { Book }_{i, t-1}} \\
& +\beta_{7} \text { Profitability }_{i, t-1}+\beta_{8} \text { Export }_{i, t-1}+\beta_{9} \text { Turnover }_{i, t} \\
& +\beta_{10} \text { Local alpha }_{i, t}+\beta_{11} \text { Global alpha }_{i, t}^{\text {ort }}+\beta_{12} \text { Board size }_{i, t-1} \\
& +\beta_{13} \text { Board independence }_{i, t-1}+\beta_{14} \text { Foreign directors }_{i, t-1} \\
& +\beta_{15} \text { Insider ownership }_{i, t-1}+\varepsilon_{i, t}
\end{aligned}
$$

As mentioned earlier, the dependent variable (FO) in Equation (7) takes three different forms of ownership, namely total foreign institutional ownership (FIO); foreign funds ownership (FFO); and foreign corporations ownership (FCO). All the explanatory variables are lagged one year to mitigate the endogeneity problem, except Turnover, Local alpha and Global alpha ${ }^{\text {ort }}$, which are market-based measures and observed by the investors more quickly. Moreover, we include year and industry dummies to control for the industry-invariant time- 
specific effects and time-invariant industry-fixed effects. In all specifications, we use robust standard errors to control for the heteroscedasticity.

\section{Empirical Results}

\subsection{Descriptive Statistics and univariate analysis}

We present in Table 2 the descriptive statistics of the variables used in the analysis. The average total ownership of foreign institutions (FIO) equals $22.4 \%$ during the sample period. This is equally divided between the ownership by foreign funds (FFO) and corporations (FCO) at $11.2 \%$. C_Score, has a mean value of 0.022 which is lower than the reported statistics for developed countries. This is in line with our expectations since emerging markets are expected to have lower average levels of conservatism due to the low level of legal enforcement and investor protection, which characterize these markets (Bushman and Piotroski 2006). ${ }^{6}$

$$
<<\text { Please insert Table } 2 \text { about here }>>
$$

In Table 3, we provide a univariate analysis of the relationship between the foreign ownership variables and the firm-specific attributes used in the analysis. To do so, we partition the sample into quartiles using the distribution of the values of ownership variables and report the average values of the explanatory variables used in the analysis for each sub-group. The quartiles 1 (Q1) and 4 (Q4) in each category represent the lowest and highest ownership subgroups, respectively. We test for multicollinearity among our regressors by checking the variance inflation factors (VIF) and we conclude that it is not a concern for our estimations. Specifically, none of the correlation coefficients between C Score, Size, Leverage and Market to Book ratio exceed 0.15 and the VIF values for other control variables do not exceed 1.5.

Panel A presents the results for foreign institutional ownership (FIO). The results show that the relationship between FIO and Size, Cash, Profitability, Dividend and Local alpha is consistently positive. That is, the average values of these variables increase monotonically 
between Q1 and Q4. However, the changes between the quartiles become less significant as the value of FIO becomes larger. On the other hand, the average values of C_Score and turnover decrease as the holdings of foreign institutional investors decrease. The relation between FIO and leverage is not clear-cut where the average leverage ratio first decreases and increases again in the highest FIO sub-group. Although the pattern is mixed in relation to the link between FIO and market-to-book and export, there is evidence that there are significant differences between the values of these variables in the lowest (Q1) and the highest (Q4) FIO sub-groups. As for the governance variables, board size, the proportion of foreign directors and insider ownership increase with the levels of FOI and the difference between the values in Q1 and Q4 is significant at $1 \%$ level.

\section{$<<$ Please insert Table 3 about here $>>$}

In Panel B, we present the univariate results for the foreign funds (FFO). The results are very similar to those presented above. However, the differences between the quartiles are more significant in the FFO sample. Moving to Panel C in Table 3, we observe that foreign corporations invest in firms which are large and have greater international sales. These earlier findings support the view that foreign corporations also invest in firms which they are better informed about. However, the relationship between FCO and other firm-specific variables is not clear-cut. For example, considering the C_Score, the lowest value is observed in the third quartile. The mean value of C_Score decreases as we move from Q1 to Q3, but the average CScore value increases in the last quarter. As foreign investors become dominant in the firm (in Q4), a low C_Score becomes less desirable. Similar pattern is also observed in cash, profitability and dividend ratios. These preliminary findings suggest that high cash level, profitability and dividend payout are less desirable if the foreign corporations are dominant in the firm. The highest market-to-book ratio is observed in the $4^{\text {th }}$ quartile, possibly suggesting that foreign corporate investors tend to hold growth stocks. Moreover, it is not possible to draw 
clear inferences about the preferences of foreign corporations regarding the leverage and market performance in the univariate analysis. Finally, the relationship between the governance variables and the preferences of foreign funds and corporations yield interesting insights. First, board size and insider shares monotonically increase as we move from Q1 to Q4 for both FFO and FCO. Board independence is the lowest in Q1 for both FFO and FCO where the difference with the value in Q4 is significant at 1 the percent level. However, the increase is not monotonic as the values in the second $(\mathrm{Q} 2)$ and third $(\mathrm{Q} 3)$ quartiles are similar to that in the fourth $(\mathrm{Q} 4)$ quartile. On the other hand, the presence of foreign directors has differential effects on the preferences of foreign funds and corporations. Differently than FFO, there is considerable increase in FCO when we move from Q1 to Q4. It seems that foreign corporations have a stronger preference for the firms with more foreign directors on the board.

\subsection{Multivariate analysis}

In this section, we investigate the determinants of foreign institutional investment by providing the results for our baseline specifications, where the three different foreign ownership variables, namely FIO, FFO and FCO, are regressed on the firm-specific variables.

Starting with the results for the FIO estimation in the first column of Table 4, we find that the relationship between accounting conservatism (C_Score) and total foreign institutional investment (FIO) is negative and significant at the $1 \%$ level. This finding is in line with the view that accounting conservatism is perceived negatively by institutional foreign investors. We can't provide support for the argument that accounting conservatism is a mechanism that mitigates the degree of asymmetric information between insiders and outsiders.

The results also reveal that the relation between FIO and size is positive and significant at the $1 \%$ level, suggesting that foreign institutional investors tend to invest in large firms which are associated with lower asymmetric information. Similarly, market-to-book ratio also exerts a positive influence in the level of total foreign institutional ownership. A one standard 
deviation increase in market-to-book ratio increases FIO by $5.1 \%$ in the following year. The positive relation possibly provides support for the view that foreign investors prefer firms with higher growth opportunities. On the other hand, the findings reveal that cash holdings, dividend payouts, leverage and exports do not have any significant impact on FIO.

Furthermore, the coefficient of Local alpha is positive and significant at the $1 \%$ level, implying that foreign investors tend to hold more shares in stocks with better past performance. However, there is no significant relationship between FIO and Global alpha, Moreover, there is a negative relationship between FIO and stock turnover, which is in line with the findings of Kang, Lee, and Park (2010). Considering the impact of governance variables on FIO, the results suggest that they prefer firms with larger boards, more foreign board directors and lower levels of insider ownership.

\section{$<<$ Please insert Table 4 about here $>>$}

Carrying out the empirical analysis separately for the ownership of foreign funds (FFO) and foreign corporations (FCO) reveal interesting findings. Importantly, the negative relationship that is reported for the relation between FIO and C_Score seems to be largely driven by the interplay between the ownership of foreign funds and accounting conservatism. This is evidenced by the negative and significant estimated coefficient of C_Score in the FFO specification in Table 4. Conservative reporting has no influence on the investment decisions of foreign corporations (FCO). As discussed earlier, differently than foreign corporations, foreign funds seek greater profits in the short-term, which makes them more sensitive to the risk-taking behavior of managers. In other words, due to their short-term orientation and riskappetite, they value firms with lower level of accounting conservatism. ${ }^{7}$

The estimated coefficients of size, market-to-book ratio and Local alpha remain qualitatively similar. Similar to the results obtained FIO, they are positive and significant for both foreign funds and foreign corporate investors, confirming the earlier findings that foreign 
institutional investors prefer larger firms, and those with greater growth opportunities and better past performance.

There are important differences between the two groups of investors regarding several other variables. For example, cash holdings exert opposite effects in the ownership of foreign funds and foreign corporations. While foreign funds seem to prefer firms with high cash reserves, foreign corporations invest more in firms with lower cash balances. This finding suggests that the agency concerns arising from high cash reserves are significant for foreign corporations, whereas foreign funds perceive greater cash balances as a desirable financial characteristic. Furthermore, we find that the estimated coefficient on profitability is positive and significant only in the FFO estimation. Another interesting finding concerns the dividend payout ratio. The influence of dividend becomes significant when we partition the investors into funds and corporations, albeit with different signs. Foreign funds invest more in firms with higher dividend payouts whereas the relation between dividend payout and ownership is negative for foreign corporations.

As argued earlier, the estimated coefficient of turnover is negative in the estimation of foreign corporations. This finding supports our view that foreign corporations can be regarded as dedicated and/or passive investors. Interestingly, the positive coefficient of Global alpha in the estimation of FCO reveals that the global performance of stocks is an important factor for foreign corporations beyond the conventional local performance measures.

Foreign funds, compared to foreign corporations, are not only more active in trading but also focus more on short-term profits than long-term ownership. They are hence likely to be more sensitive to the presence of informational asymmetry, which increases the cost of monitoring and decreases short-term benefits. Similarly, profitability is significant only in the FFO estimation. The positive coefficient of ROA suggests that foreign funds prefer firms with greater accounting profitability. 
The results for the governance variables are also interesting. Board size and board independence have a significant positive impact on the foreign funds ownership. However, the presence of foreign directors and insider shareholding do not exert any influence on FFO. Nevertheless, insider shareholdings and the presence of foreign directors impact the investment decisions of corporations (FCO) more significantly. Specifically, foreign corporate investors prefer firms with a greater number of foreign directors and lower insider shareholdings which are insignificant in the FFO estimation.

Overall, our findings support our expectations that foreign funds and foreign corporations have different motives in terms of investment decisions and in turn they prefer different classes of stocks. Therefore, disaggregating the investors into different types is not trivial to understand the investment behavior of foreign institutional investors. Moreover, conservative reporting has a significant impact on the preferences of foreign funds and it acts as a negative factor that reduces the potential short-term profits, rather than being a corporate governance mechanism.

\section{Additional Tests}

\subsection{Analysis by information asymmetry and board structure sub-groups}

Our baseline results suggest that conservative reporting plays a key role in understanding the behavior of foreign institutional investors (particularly for the foreign funds) in general. In this section, we provide further analysis by dividing the sample into sub-groups using bid-ask $\operatorname{spread}^{8}$ and size to serve as an indicator of asymmetric information. In this respect, we group firms into high/low bid-ask spread and large/small size categories using the sample median value. Low (high) bid-ask spread and large (small) firms are identified as low (high) information asymmetry group of firms. We then run regressions separately for each category to compare the impact of explanatory variables, including C_Score, on foreign funds' ownership conditional on information asymmetry. We carry out the analysis only for foreign funds as the 
relation between conservative reporting and ownership is significant only for this group of institutional investors.

\section{$<<$ Please insert Table 5 about here $>>$}

The results in Table 5 provide several interesting insights. First, accounting conservatism exerts a negative and significant impact only in the low asymmetric information sub-sample of firms. The negative coefficient of C_Score suggests that foreign funds perceive the accounting conservatism as a strong indicator of the presence of asymmetric information problems in firms that are normally perceived to have a lower degree of asymmetric information. This result is consistent with the signaling hypothesis that firms with lower information asymmetry adopt more conservative reporting practices to distinguish themselves from the firms with greater information asymmetry. Given that conservative reporting is a response to the asymmetric information problem within the firm, being conservative in the absence of asymmetric information problems is perceived negatively by foreign funds.

Another possible explanation is that conservative reporting is seen as a mechanism that forces managers to engage in less risky investments which may consequently lead managers to pass up profitable projects and in turn decrease firm value. The findings suggest that this feature of accounting conservatism is not desirable by foreign funds who normally seek greater shortterm performance instead of long-term financial well-being.

After controlling for information asymmetry, the estimated coefficients of size are positive and significant at $1 \%$ level. This confirms the earlier strong and consistent findings that foreign institutions prefer to invest in large firms regardless of the information asymmetry level. Similar findings are obtained for the market-to-book ratio and local alpha.

As for cash holdings, it seems that the degree of information asymmetry makes a difference for the relation between cash balances and ownership levels of foreign funds. The effect of cash balances on investment is positive and significant only in low asymmetric 
information firms. It seems that the earlier positive finding in Table 4 between cash and investment for foreign funds is mostly conditional on the level of information asymmetry. This result may suggest that foreign funds see high cash holdings as a factor which makes their investment safer especially in the short term if the information asymmetry within the corporation is low. On the other hand, the desirable feature of high cash holdings disappears as the information asymmetry increases since high cash reserves may increase the severity of the agency problems by motivating the managers to invest in negative NPV projects.

The interplay between profitability and foreign investment also changes with the degree of information asymmetry. However, the findings are not clear cut. Consistent with our earlier findings, the influence of profitability on investment is positive for the low asymmetric information sub-group and also for small firms. However, the estimated coefficient of profitability is insignificant for the high bid-ask spread sub-group.

As for the dividend payout policy of firms, the findings reveal that in firms with low information asymmetry dividend exerts a significant positive effect on foreign funds ownership. However, when the extent of asymmetric information is high, foreign funds do not seem to be sensitive to dividend payouts. Again, similarly to the implications of the findings for profitability, foreign funds value higher dividends more when the concerns over asymmetric information are lessened.

The role of leverage in attracting foreign funds is opposite of the role of cash, dividend payouts and profitability. Specifically, the debt ratio of companies has a positive and significant impact on the ownership decisions of foreign funds only in firms with high informational asymmetry. This is an interesting finding to reveal more clearly the role of information asymmetry on the investment decisions of foreign funds. Given that leverage can be considered as a corporate governance device that is likely to mitigate the agency problems within firms, foreign funds perceive high leverage as a positive feature from an agency point of view. This 
is possibly because low leverage in firms with higher informational problems may increase the severity of the costs associated with the information asymmetry.

The findings regarding the impact of local and global performances on foreign ownership are also important. The effect of local performance on the preferences of foreign funds is positive and significant in all sub-groups. In contrast, global performance does not provide any significance for any of the sub-groups.

The analysis of the impact of corporate governance characteristics on foreign ownership in different sub-groups is also interesting. Differently than our expectations, board independence is significant only for large firms and those with lower bid-ask spreads. On the other hand, as expected, larger insider ownership is not desirable if the firm suffers from information asymmetries. The relationship between board size and foreign directors is not unambiguous. Board size exerts a positive impact on FFO except for the large sub-group. Interestingly, the presence of foreign directors is significant only for the small sub-group. These results confirm the important role of firm size on the interplay between the investment preferences of foreign funds and informational asymmetries.

\section{$<<$ Please insert Table 6 about here $>>$}

As an additional test, we also divide our sample into two according to the monitoring effectiveness of the board which is proxied by board size and board independence. We classify firms into sub-groups according to board size and board independence using their median values. We expect to find a negative relation between C_Score and foreign ownership only for the firms with larger boards and greater board independence. Using the same explanations provided earlier regarding the role of information asymmetry, we argue that greater conservatism may be regarded as unnecessary by the foreign investors if the board already monitors the managerial activities effectively. The results reported in Table 6 are in line with 
our expectations. Foreign investors do not prefer firms with greater conservatism if there is sufficient monitoring within the firm.

\subsection{Controlling for firms with zero foreign ownership}

Another additional analysis relates to the fact that about $30 \%$ of the firms in the sample record zero ownership by foreign funds and foreign corporations. One can hence argue that some of the findings may be driven by the frequency of zero ownership data points. To ensure the robustness of our findings and address the potential concerns, we estimate our main specifications using data only for firms that report non-zero foreign ownership. As an additional check, we also employ Tobit regression as an alternative specification, which considers the observations with zero-ownership as censored data. Table 7 Panel A presents our results. We do not report the results about the control variables for brevity.

\section{$<<$ Please insert Table 7 about here $>>$}

The findings remain largely unchanged, albeit the small differences in the estimated coefficient of C_Score. The coefficient of C_Score is still negative after addressing the zero foreign ownership issue.

\subsection{Alternative measures of foreign institutional ownership}

In addition to the specification of the ownership level, several studies estimate foreign ownership relative to the market portfolio. Following Dahlquist and Robertsson (2001), we specify our dependent variables as the ratio of foreign portfolio weight in firm $i$ to the weight of firm $i$ in the value-weighted market portfolio. Our final estimation of foreign ownership is as follows:

$$
y_{i, t}=\omega_{i, t}^{F} / \omega_{i, t}^{M}-1
$$


In Equation (8), $\omega_{i, t}^{F}$ and $\omega_{i, t}^{M}$ represent the weight of firm in the foreigners' and market portfolio, respectively. A positive value indicates that foreign investors hold disproportionally more shares in the firm.

As an additional analysis, we also measure foreign ownership relative to the market capitalization rather than the value of floating shares since large insider ownership which technically lowers the float-based foreign ownership may have an impact on the corporate reporting practices. As it is shown in Panel B of Table 7, the majority of our primary findings are not sensitive to the alternative specification of foreign ownership. C_Score is still meaningful in the estimation of foreign funds' ownership.

\subsection{Endogeneity concerns}

One of the important assumptions of the OLS regressions is the exogeneity of the explanatory variables. It can be argued that some of the firm specific variables used in the analysis, as well as the C_Score, are endogenously determined. One potential problem is that both C_Score and foreign ownership may be determined by unobservable firm characteristics which are not included in the empirical model. Although we attempt to control in the estimations for the effects of several accounting, market and governance variables, the results can hence be biased by unobservable firm characteristics. To account for the endogeneity concerns arising from this, we employ three different tests.

Firstly, instead of estimating the model with industry fixed effects, we include firm-fixed effects by clustering the standard errors at the firm level in our estimations to control for unobservable time-invariant firm-specific effects that may affect foreign institutional ownership. We note that fixed effects estimations may not fully address the endogeneity problem if the endogeneity arises from other unobservable time-variant variables. Moreover, foreign ownership can be determined simultaneously with the C_Score or past ownership 
levels. Accordingly, as a second test, we employ Arellano-Bond's (1991) dynamic GMM estimations by treating the explanatory variables as endogenous and use their lagged values as the instruments. Another advantage of this estimation is that we can still suppress the impact of firm-fixed effects by first differencing. Additionally, we include the lagged dependent variable among the other regressors to incorporate in the analysis the dynamic nature of the foreign ownership decisions. The findings are presented in Panel $\mathrm{C}$ of Table 7. We do not report the results for the control variables for brevity. Consistent with our earlier findings, the estimated coefficient of C_Score is negative and significant in fixed-effects and GMM estimations.

Thirdly, to further address the endogenity concerns, we employ propensity score matching analysis. This analysis allows us to compare the high and low C_Score groups which are similar in many respects except foreign ownership and isolate the impact of C_Score from the other firm-specific factors included in the analysis. This process is implemented in two stages. In the first stage, we form three groups according to the C_Score terciles and we match each firm in the first tercile with another firm in the last tercile according to several firm-specific variables by using the nearest neighbor matching technique. We also require the maximum distance between the propensity score to not exceed 0.01 . Finally, we also require the treatment (High C_Score) and control groups (Low C_Score) matched exactly by time. We then compare the values of FFO and FCO in the treatment sample with those in the control sample after oneto-one matching. We match the firms in the two groups according to accounting and market variables (Match 1), governance variables (Match 2) and accounting, market and governance variables (Match 3). According to the results in Table 8, FFO significantly differs in the treatment (High C_Score) and control (Low C_Score) samples at 1\% level. FFO is significantly lower in the high C_Score group for all of the matching samples. However, we do not observe any differences in FCO between the treatment and control groups. 
Overall, the detailed robustness analysis provides evidence that our findings are not subject to biases that may arise from potential omitted variables and endogeneity problems. The main finding that conservative reporting has a negative impact on foreign funds ownership remains unchanged under alternative specifications.

$<<$ Please insert Table 8 about here $>>$

\subsection{Impact of global financial crisis}

Given that the global financial crisis had a considerable impact on the borrowing capacity of firms and the opportunistic behavior of managers, it is reasonable to expect a change in the role of information asymmetry on foreign investor behavior in the aftermath of the financial crisis. To shed further light on this issue, we examine if the relationship between foreign institutional ownership and accounting conservatism changes with the global financial crisis of 2007-2009. To do so, we interact C_Score with a post-crisis dummy which takes the value of 1 if the investment takes place in the post-crisis period, and zero otherwise. The post-crisis period in our sample corresponds to the period 2010-2015. Untabulated results reveal that foreign ownership decreases after the global financial crisis, evidenced by the negative coefficient of the crisis dummy variable. Moreover, the estimated coefficient of the interaction term is negative and significant, suggesting that the negative relation between accounting conservatism and ownership of foreign funds becomes stronger in the post-crisis period. We find that for foreign corporations the relationship between accounting conservatism and ownership remains qualitatively similar.

\section{Summary and conclusions}

The objective of this paper has been to investigate the determinants of corporate ownership decisions of foreign institutional investors in an emerging market setting, which is characterized by informational asymmetry and agency conflicts between insiders and outside investors. There 
are two main novelties of this study, which extends knowledge on the topics of foreign institutional investment and financial reporting. First, differently from previous research, this study incorporates accounting conservatism in the analysis of foreign institutional ownership. Second, it explicitly addresses the potential differences in investment motives and incentives of different types of institutional ownership, namely foreign funds and foreign corporations.

The results provide important insights. It is shown that the factors determining the equity ownership of foreign funds and corporations in domestic firms are different. Foreign funds (corporations) choose to invest in firms with high (low) cash, dividend and leverage. Nevertheless, both groups of foreign investors have greater ownership in large and high growth firms. More importantly, our analysis provides strong evidence that conservative reporting is not desired by foreign investors and has a negative impact on their ownership in domestic firms. Further investigation reveals that the interaction between conservative reporting and ownership differs significantly between foreign funds and corporations. That is, conservative reporting impacts only the investment decisions of foreign funds, whereas foreign corporations are indifferent to the extent of conservative reporting. More interestingly, foreign funds behave similarly to corporations in high-asymmetric information firms and reduce ownership in lowasymmetric information firms when such firms adopt conservative reporting practices. Additional analysis in the study indicates that the negative relation between conservative reporting and the equity investment decisions of foreign funds becomes stronger after the global financial crisis. Our results are robust to endogeneity and omitted variable biases.

The findings of our analysis are important for at least two reasons. First, we believe that they lead to a better understanding of the factors that influence the investment decisions of different types of foreign institutional investors in emerging markets. Second, the results shed significant lights on the (ir)relevance of conservative reporting in alleviating the negative impact of asymmetric information on foreign institutional investment. Consequently, our 
analysis and its findings raise new research questions as to the value of conservative reporting where the investors differ in their time horizons and objectives of portfolio investments. Also, there is further need for research on the measurement and interpretation of informational problems by employing data from a diversified sample of countries and firms. This awaits future research.

\section{Notes}

1. We do not include individual investors in our analysis since foreign individual investors hold less than $1 \%$ of total equity holdings of listed Turkish firms.

2. Van Nieuwerburgh and Veldkamp (2009) suggest that each investor group tend to consolidate their advantageous position by investing in line with their own information set. This in turn increases the information asymmetry between local and foreign investors and motivate each group to invest in different stocks which they are more informed about.

3. It is reported by the World Economic Forum that the countries with the strongest accounting auditing and reporting standards are Finland, Norway, Singapore, New Zealand and Canada with scores above 6 out of 7. Turkey has a score of 4.3 with some of the other emerging countries such as China, South Korea, and Malaysia having scores of 4.5, 4.7, and 5.5 respectively. The data is available from http://reports.weforum.org/global-competitiveness-index-2017-2018/competitivenessrankings/\#series $=$ EOSQ097

4. The lowest and highest free-float capitalization rates of foreign ownership are $62 \%$ and $72 \%$ in 2011 and 2007 respectively. These numbers are based on our own calculations from the official reports.

5. There is a strand of literature which also acknowledges the relevance of accounting conservatism in determining the value of debt. For example, Cai, Helwega, and Warga (2007) suggest that information-based arguments of conservatism are more relevant to debt financing. In a similar vein, Ball and Shivakumar (2005) state that conditional conservatism increases the contract efficiency by providing additional information to the creditors. In a more recent study, Liu and Magnan (2014) provide evidence on the impact of accounting conservatism on the pricing of newly issued corporate bonds. They find that conservatism results in greater underpricing of newly issued corporate bonds as conservative reporting is perceived as a signal for the informational advantage of insiders over outsiders. Similarly, Liu and Magnan (2016) show that conservative reporting leads to greater yields on corporate bonds.

6. For US, Ahmed and Duellman (2013) and Kravet (2014) report the average value of C_Score as 0.06 and 0.165 , respectively. However, Andre et al. report the average value of C_Score as -0.09 for 16 European countries including advanced and emerging markets. 
7. For robustness purposes, we also make additional estimations by clustering the standard errors at the firm level. Our main conclusions regarding the impact of accounting conservatism on foreign institutional ownership do not change albeit small differences on the estimated coefficients of control variables. The results are available upon request from the authors.

8. Yearly bid-ask spread is calculated averaging daily bid-ask spreads in a given year where daily bidask spread is measured by the ratio of (Ask price-bid price) to (Ask price+bid price)/2. 


\section{References}

Adams, Reene B., Benjamin E. Hermalin, and Michael S. Weisbach. 2010. "The Role of Boards of Directors in Corporate Governance: A Conceptual Framework and Survey.” Journal of Economic Literature 48(1): 58-107.

Aggarwal, Reena, Leora Klapper, and Peter D. Wysocki. 2005. "Portfolio Preferences of Foreign Institutional Investors." Journal of Banking \& Finance 29 (12): 2919-2946.

Ahmed, Anwer S., and Scott Duellman. 2013. "Managerial Overconfidence and Accounting Conservatism." Journal of Accounting Research 51 (1): 1-30.

Allen, Franklin, and Gerald R. Faulhaber. 1989. "Signalling by Underpricing in the IPO Market." Journal of Financial Economics 23(2): 303-323.

André, Paul, Andrei Filip, and Luc Paugam. 2015. "The Effect of Mandatory IFRS Adoption on Conditional Conservatism in Europe." Journal of Business Finance \& Accounting, 42(3-4): 482-514.

Arellano, Manuel, and Stephen Bond. 1991. "Some Tests of Specification for Panel Data: Monte Carlo Evidence and An Application to Employment Equations." The Review of Economic Studies 58(2): 277-297.

Ball, Ray, and Lakshmanan Shivakumar. 2005. "Earnings Quality in UK Private Firms: Comparative Loss Recognition Timeliness." Journal of Accounting and Economics 39(1): 83-128.

Ball, Ray, S. P. Kothari, and Valeri V. Nikolaev. (2012). "On Estimating Conditional Conservatism." The Accounting Review 88(3): 755-787.

Basu, Sudipta. 1997. "The Conservatism Principle and the Asymmetric Timeliness of Earnings." Journal of Accounting and Economics 24 (1): 3-37.

Bertomeu, Jeremy, Masako Darrough, and Wenjie Xue. 2017. "Optimal Conservatism with Earnings Manipulation." Contemporary Accounting Research 34 (1): 252-284.

Bushman, Robert M., and Joseph D. Piotroski. 2006. "Financial Reporting Incentives for Conservative Accounting: The Influence of Legal and Political Institutions." Journal of Accounting and Economics 42 (1-2): 107-148. 
Cai, Nianyun, Jean Helwege, and Arthur Warga. 2007. "Underpricing in the Corporate Bond Market." Review of Financial Studies 20 (6): 2021-2046.

Cheng, Shijun. 2008. "Board Size and the Variability of Corporate Performance." Journal of Financial Economics 87(1): 157-176.

Choe, Hyuk, Bong-Chan Kho, and René M. Stulz. 2005. "Do Domestic Investors Have an Edge? The Trading Experience of Foreign Investors in Korea." The Review of Financial Studies 18 (3): 795-829.

Covrig, Vicentiu, Sie Ting Lau, and Lilian Ng. 2006. "Do Domestic and Foreign Fund Managers Have Similar Preferences for Stock Characteristics? A Cross-country Analysis." Journal of International Business Studies 37 (3): 407-429.

Dahlquist, Magnus, Lee Pinkowitz, Rene M. Stulz, and Rohan Williamson. 2003. "Corporate Governance and the Home Bias." Journal of Financial and Quantitative Analysis 38 (1): 87-110.

Dahlquist, Magnus, and Göran Robertsson. 2001. "Direct Foreign Ownership, Institutional Investors, and Firm Characteristics." Journal of Financial Economics 59 (3): 413-440.

Douma, Sytse, Rejie George, and Rezaul Kabir. 2006. "Foreign and Domestic Ownership, Business Groups, and Firm Performance: Evidence from a Large Emerging Market." Strategic Management Journal 27 (7): 637-657.

Fama, Eugene F., and Michael C. Jensen. 1983. "Separation of Ownership and Control." The Journal of Law and Economics 26(2): 301-325.

Fama, Eugene F., and Kenneth R. French. 1995. "Size and Book-to-market Factors in Earnings and Returns." The Journal of Finance 50 (1): 131-155.

Giannetti, Mariassunta, and Andrei Simonov. 2006. "Which Investors Fear Expropriation? Evidence from Investors' Portfolio Choices." The Journal of Finance 61 (3): 1507-1547.

Grinblatt, Mark, and Matti Keloharju. 2000. "The Investment Behavior and Performance of Various Investor Types: A Study of Finland's Unique Data Set." Journal of Financial Economics 55 (1): 43-67.

Guest, Paul M. 2009. “The Impact of Board Size on Firm Performance: Evidence from the UK." The European Journal of Finance 15(4): 385-404. 
Harford, Jarrad, Sattar A. Mansi, and William F. Maxwell. 2012. "Corporate Governance and Firm Cash Holdings in the US." Corporate governance. Springer Berlin Heidelberg,

Harvey, Campbell R., Karl V. Lins, and Andrew H. Roper. 2004. "The Effect of Capital Structure when Expected Agency Costs are Extreme." Journal of Financial Economics 74 (1): 3-30.

Jensen, Michael C. 1986. "Agency Costs of Free Cash Flow, Corporate Finance, and Takeovers." The American Economic Review 76 (2): 323-329.

Jensen, Michael C. 1993. "The Modern Industrial Revolution, Exit, and the Failure of Internal Control Systems." The Journal of Finance 48(3): 831-880.

Jensen, Michael C., and William H. Meckling. 1976. "Theory of the Firm: Managerial Behavior, Agency Costs and Ownership Structure." Journal of Financial Economics 3(4): 305-360.

Jiang, Li, and Jeong-Bon Kim. 2004. "Foreign Equity Ownership and Information Asymmetry: Evidence from Japan." Journal of International Financial Management \& Accounting 15 (3): 185-211.

Kang, Hyung Cheol, Dong Wook Lee, and Kyung Suh Park. 2010. "Does the Difference in Valuation Between Domestic and Foreign Investors Help Explain Their Distinct Holdings of Domestic Stocks?" Journal of Banking \& Finance 34 (12): 2886-2896.

Kang, Jun-Koo, Rene Stulz. 1997. "Why is There a Home Bias? An Analysis of Foreign Portfolio Equity Ownership in Japan." Journal of Financial Economics 46 (1): 3-28.

Kim, Jeong Bon, and Liandong Zhang. 2016. “Accounting Conservatism and Stock Price Crash risk: Firm-level Evidence." Contemporary Accounting Research 33(1): 412-441.

Khan, Mozaffar, and Ross L. Watts. 2009. "Estimation and Empirical Properties of a Firm-year Measure of Accounting Conservatism." Journal of Accounting and Economics 48 (2): 132150.

Kravet, Todd D. 2014. "Accounting Conservatism and Managerial Risk-taking: Corporate Acquisitions." Journal of Accounting and Economics 57 (2): 218-240. 
La Porta, Rafael, Florencio Lopez-de-Silanes, Andrei Shleifer, and Robert Vishny. 2000. "Investor Protection and Corporate Governance." Journal of Financial Economics 58(1): $3-27$.

LaFond, Ryan, and Sugata Roychowdhury. 2008. "Managerial Ownership and Accounting Conservatism." Journal of Accounting Research 46(1): 101-135.

LaFond, Ryan, and Ross L. Watts. 2008. "The Information Role of Conservatism." The Accounting Review 83(2): 447-478.

Lara, Juan Manuel García, Beatriz García Osma, and Fernando Penalva. 2011. "Conditional Conservatism and Cost of Capital." Review of Accounting Studies 16 (2): 247-271.

Lara, Juan Manuel García, Beatriz García Osma, and Fernando Penalva. 2016. "Accounting Conservatism and Firm Investment Efficiency." Journal of Accounting and Economics 61 (1): 221-238.

Leuz, Christian, Karl V. Lins, and Francis E. Warnock. 2008. "Do Foreigners Invest Less in Poorly Governed Firms?." The Review of Financial Studies 22 (8): 3245-3285.

Li, Xi. 2015. "Accounting Conservatism and the Cost of Capital: An International Analysis." Journal of Business Finance \& Accounting 42(5-6): 555-582.

Lin, Anchor Y., and Peggy E. Swanson. 2003. "The Behavior and Performance of Foreign Investors in Emerging Equity Markets: Evidence from Taiwan." International Review of Finance 4(3-4): 189-210.

Lin, Z. Jun., and Zhimin Tian. 2012. "Accounting conservatism and IPO underpricing: China evidence." Journal of International Accounting, Auditing and Taxation 21 (2): 127-144.

Liu, Mingzhi, and Michel Magnan. 2014. "Conditional Conservatism and Underpricing in US Corporate Bond Market.” Applied Financial Economics, 24 (20): 1323-1334.

Liu, Mingzhi, and Michel Magnan. 2016. "Conditional Conservatism and the Yield Spread of Corporate Bond Issues." Review of Quantitative Finance and Accounting, 46 (4): 847-879.

Liu, Ningyue, Don Bredin, Liming Wang, and Zhihong Yi. 2014. "Domestic and Foreign Institutional Investors' Behavior in China." The European Journal of Finance 20 (7-9): 728-751. 
Masulis, Ronald W., Cong Wang, and Fei Xie. 2012. "Globalizing the Boardroom-The Effects of Foreign Directors on Corporate Governance and Firm Performance." Journal of Accounting and Economics, 53(3): 527-554.

Min, Byung S., and Robert G. Bowman. 2015. "Corporate Governance, Regulation and Foreign Equity Ownership: Lessons from Korea." Economic Modelling 47: 145-155.

Opler, Tim, Lee Pinkowitz, Rene Stulz, and Rohan Williamson. 1999. "The Determinants and Implications of Corporate Cash Holdings." Journal of Financial Economics 52 (1): 3-46.

Ozkan, Aydin, and Neslihan Ozkan. 2004. "Corporate Cash Holdings: An Empirical Investigation of UK Companies." Journal of Banking \& Finance 28 (9): 2103-2134.

Ramalingegowda, Santhosh, and Yong Yu. 2012. "Institutional Ownership and Conservatism." Journal of Accounting and Economics 53 (1): 98-114.

Ross, Stephen A. 1977. "The Determination of Financial Structure: The Incentive-signalling Approach." The Bell Journal of Economics 8(1): 23-40.

Roychowdhury, Sugata. 2010. "Discussion of Acquisition Profitability and Timely Loss Recognition" by J. Francis and X. Martin." Journal of Accounting and Economics 49 (1): 179-183.

Suijs, Jeroen. 2008. "On the Value Relevance of Asymmetric Financial Reporting Policies." Journal of Accounting Research 46 (5): 1297-1321.

Van Nieuwerburgh, Stijn, and Laura Veldkamp. 2009. "Information Immobility and the Home Bias Puzzle." The Journal of Finance 64 (3): 1187-1215.

Watts, Ross L. 2003. "Conservatism in Accounting Part I: Explanations and Implications." Accounting Horizons 17 (3): 207-221.

Zou, Liping, Tiantian Tang, and Xiaoming Li. 2016. "The Stock Preferences of Domestic versus Foreign Investors: Evidence from Qualified Foreign Institutional Investors (QFIIs) in China." Journal of Multinational Financial Management 37: 12-28. 